\title{
Legal Regime of Digital Rights
}

Kambariddin M. Mehmonov, Doctor of Philosophy in Law Sciences (PhD), Associate Professor, Department of Civil Law Tashkent State Law University Tashkent city, the Republic of Uzbekistan

Elbek T. Musaev, Candidate of Law, Acting Associate Professor, Department of Civil Law, Tashkent State Law University Tashkent city, the Republic of Uzbekistan

\begin{abstract}
This article analyzes the legal regime of digital rights. The research proposed in the article aims to give a holistic idea of what digital law is, what are its features, to identify gaps in legislation and problems of law enforcement in civil law relations. Also, the scientific views of scientists, the strategy of the legislation of the Republic of Uzbekistan in the era of digitalization of the economy, the application of civil legislation to relations related to digital rights are considered. In conclusion, the author gives suggestions for improving the legislation.
\end{abstract}

Keywords: Digital law, token, big data, legal regime, features of digital rights, improvement of legislation.. Received: 05.12.2020 Accepted: 10.01.2021 $\quad$ Published: 03.02.2021

\section{INTRODUCTION}

Today it is no secret to anyone that digital rights are increasingly being introduced into our social life, requiring significant financial, economic and labor resources, and are gradually pushing away ordinary unnecessary material carriers. However, this does not mean the exclusion of other related objects from civil circulation.

In the XXI century, so much information has accumulated that knowledge and skills require a systematic approach for implementation and use in civil circulation. The most requested and requested resources are, of course, information.

In Uzbekistan, the implementation of more than 220 priority projects has begun, providing for the improvement of the e-government system, the further development of the domestic market of software products and information technologies, the organization of IT parks in all regions of the republic, and the provision of this sector with qualified personnel.

The introduction of information and communication technologies in various spheres of public life in the Republic of Uzbekistan requires adequate effective legal regulation of this industry. Novels and law enforcement practice in the field of computer technologies mainly appear in the territory where they are created, that is, they are based on the practice of foreign countries. In our country, on October 5, 2020, the Strategy "Digital Uzbekistan - 2030" was adopted, according to which it is planned to introduce over 280 information systems and software products to automate management, production and logistics processes at enterprises of the real sector of the economy.

Although, in the Republic of Uzbekistan there is a certain legal basis in relation to objects of digital rights, there is no single systemic scientific approach. These circumstances make actual legal problems related to the creation, use and implementation of digital rights in civil circulation.

Today, various technological platforms such as blockchain, Internet of Things, Artificial intelligence, Big Data, etc. are actively used in a wide variety of areas of human activity. The use of social networks and platforms Facebook, VK, Twitter, etc. is also of great importance. These technologies require new conditions, realities and approaches to civil law regulation.

In the United States, in 2017, a legislative definition regarding artificial intelligence was not adopted, and is still open to debate. Administrative and legal regulation will not give a positive effect, as it may contradict private interests. It is civil science that should provide answers to the questions posed.

The definition of the legal regime of digital rights, the exercise and protection of personal nonproperty, property and exclusive rights create not only scientific and theoretical problems, but also disputes in law enforcement practice. In particular, in various government bodies, institutions, courts, the department of bailiffs, certain digital rights are created and used. However, is the creative work of an individual required to create digital rights? What features are inherent in these objects of civil law? All these issues and circumstance put on the agenda the implementation of separate studies on the implementation and protection of rights in relation to digital rights. Based on this, we consider it relevant to analyze the legal regime and the peculiarity of digital law among other objects of civil law under the legislation of the Republic of Uzbekistan. 
Uzbek legislation is being adapted to the conditions of widespread use of digital technologies in various fields of activity. In particular, cadastral documents, determination of utility bills, receipt of public services via my.gov.uz, etc. Based on the Order of the President of the Republic of Uzbekistan "On measures to improve the civil legislation of the Republic of Uzbekistan" No. R-5464 dated 05.04.2019. proposals are made to improve civil law regarding digital rights, which have already been introduced in Article 141.1. Civil Code of the Russian Federation, which entered into force on October 1, 2019.

Along with this, it is necessary to amend Article 81 of the Civil Code of the Republic of Uzbekistan, according to which, among the objects of civil rights, along with things (including cash and documentary securities), it is advisable to include other property, including non-cash funds, non-documentary securities and digital rights. In addition, the written form of the transaction is considered to be complied with if it was made using electronic or other technical means that make it possible to reproduce the content of the transaction unchanged on a tangible medium.

Although, ahead of time in the current edition of the Civil Code of the Republic of Uzbekistan, which is already 20 years old, Article 366 provides for a similar method of concluding an agreement, according to which an agreement in writing can be concluded by drawing up one document signed by the parties, as well as by exchanging documents through postal, telegraph, teletype, telephone, electronic or other communication, allowing you to reliably establish that the document comes from a party to the contract. This article emphasizes the identification of the parties to the legal relationship, which in fact will be present in digital rights.

Note that the above article often applies when granting the right to use computer programs and databases. In this case, the law allows the conclusion of an agreement on the provision of a simple nonexclusive license in a simplified manner through the performance of implicit actions (Article 1036 of the Civil Code of the Republic of Uzbekistan).

At the current stage of development of civil law relations, it is necessary to introduce a new concept of "automated execution of obligations" into civil circulation, that is, obligations arising from a transaction without a separately expressed will of the parties through the use of information technologies determined by the terms of the transaction. Such fulfillment of obligations has long been widespread in practice. The simplest version of this method is, for example, confirmation of invoices, an act of work performed, services rendered by means of an electronic digital signature of the parties, or debiting from an account specified by the subscriber of a certain amount by agreement to top up the balance on the phone.

The development of electronic control technologies, carried out using digital technologies and Big Date, in the near future will radically change the idea of state and law. Today, almost every government agency, organization or even an individual forms various options for the digital image of citizens.

Indeed, every day we submit various data about ourselves indicating our identification data, as well as about the owner of property, consumer, participant in civil law relations, which are entered into the information system of various levels (identification of a person, person, means of payment, etc.)

According to A.A. Kartskhia, digital rights are recognized as a type of property rights. They will be able to certify the rights to all objects of civil rights, (except for intangible benefits) to participate in civil legal relations, as objects of civil circulation. According to RI Sitdikova and R.B.Sitdikov, the introduction of the concept of "digital law" will require changes in various areas of legal regulation, clarification of some basic concepts. This means the establishment of a legal regime of "digital rights", especially the civil regulation of relations associated with it.

As EN Agibalova notes, the definition of the concept of "digital rights" has become so extensive that it can include any rights recorded in digital form. The norms of the Civil Code of the Russian Federation on digital rights are rather declarative in nature and only state that digital rights exist as objects of civil rights and relate to property rights in the information system. V. Zorkin also understands digital rights as "the right of people to access, use, create and publish digital works, to access and use computers and other electronic devices, as well as information networks, in particular to the Internet". However, this does not mean only the digitalization of civil rights objects or a change in the information carrier.

An interesting point of view is given by A. Sidikov, in whose opinion, unlike other objects of property law, an object of digital law, whether it is a digital signature or another, can be copied, i.e. multiply, while not decreasing in the basic version, being remote and / or spoiled in the digital sense of the word.

According to L.A. Rodionov, enshrined in the Civil Code of the Russian Federation of the basic concept of "digital rights" is a legal analogue of the term "token". Supporting the opinion of L.A. Rodionov, M.A.Rozhkova notes that the tokens in the Civil Code of the Russian Federation are named as "digital rights". And the use of tokens is a significant moment characteristic of a private (private) blockchain.. 
Continuing his remark, the author notes that a token is a record in electronic (digital) form, certifying real, obligation and other property rights or other, including intangible, good of interest to the token holder.

In our opinion, it is necessary to pay attention to the fact that digital rights may be associated with contractual rights. In particular, utilitarian digital law arises in an investment platform in three varieties: 1) the right to demand the transfer of a thing (things), other than real estate; 2) the right to demand the transfer of exclusive rights to the results of intellectual activity and (or) the rights to use the results of intellectual activity, except for patent rights; 3) the right to demand the performance of work and (or) the provision of services.

The provision in the legal novels "named in this capacity in the law", "corresponding to the characteristics established by law" make it possible to gradually, in more detail regulate civil legal relations associated with digital rights.

The term "digital rights" is interpreted in the world in a completely different way from what the legislator proposed, namely as "human rights in the digital space"..

The question arises - is cryptocurrency a digital right or an object of civil rights? So far, at the legislative level, cryptocurrency is not included in digital law. Although the circulation of cryptocurrencies should apply the rules on digital rights, for example, when they can be used as a means of payment as a legal relationship.

According to S.V. Sarbash digital law is the registration of any known law: property, obligation, corporate, exclusive, personal, i.e. only its form, no more.

According to R.S. Bevzenko, digital rights are not an independent type of objects of civil rights. This is a form of existence of property rights.

In our opinion, the question should be raised not only regarding the environment and properties of law, but specifically regarding the content of rights and obligations that form the content of the relevant legal relationship. The new digital form of the old existing rights does not change the essence of legal relations, but only indicates the appropriate environment. Digital law is a new way of fixing obligations and other rights. There are features of the subject composition, the form of consolidation and transfer of rights, the content of the legal relationship. Although some experts believe that all this does not mean the emergence of a new type of rights as such.

In our opinion, the norms that will regulate digital rights are primarily based on the adaptation of civil legislation and thereby establish a legal regime for digital rights. The main thing is to define the concept of "digital rights" in the Civil Code as an object of civil rights.

In our opinion, article 166 of the draft Civil Code of the Republic of Uzbekistan should be presented in the following edition, which establishes the legal regime of digital law:

\section{"Article 166. Digital rights}

Digital rights are a law of obligation and other rights provided by law as digital rights and determined in accordance with the rules of the information system, the content and conditions for the implementation of which correspond to the features provided by law.

The implementation, disposal of digital rights, including transfer to another person, pledge, prohibition or restriction of digital rights, can only be carried out in the information system without contacting third parties.

Unless otherwise provided by law, the person who can dispose of this right in accordance with the rules of the information system is recognized as the owner of the digital right. Another person may be recognized as the owner of a digital right on the grounds and in cases provided by law.

The consent of the person who has committed himself to this digital right is not required to transfer digital rights to another person by agreement. "

\section{References}

1. ${ }^{1}$ Decree of the President of the Republic of Uzbekistan "On approval of the Strategy" Digital Uzbekistan - 2030 "and measures for its effective implementation" No. UP-6079 of 05.10.2020 // National database of legislation, 06.10.2020, No. 06/20/6079 / 1349.

2. $1 / /$ National database of legislation, 06.04.2019, No. 08/19/5464/2891.

3. 1 Federal Law of 18.03.2019 N 34-FZ "On Amendments to Parts One, Two and Article 1124 of Part Three of the Civil Code of the Russian Federation" // Collected Legislation of the Russian Federation, 03.25.2019, N 12, Art. 1224

4. ${ }^{1}$ Ovchinnikov A. Digital rights as objects of civil rights // Philosophy of law, 2019. No. 3 (90). P. 110.

5. ${ }^{1}$ Kartskhia A.A. Digital Rights and Law Enforcement // Monitoring of Law Enforcement No. 2 (31) 2019, DOI: 10.21681 / 2226-0692-2019-2. P.44. 
6. 1 Sitdikova R.I., Sitdikov R.B. Digital rights as a new type of property rights // Property relations in the Russian Federation. 2018. No. 9 (204). P.79.

7. ${ }^{1}$ Agibalova E.N. Digital rights in the system of objects of civil rights // Legal Bulletin of the Dagestan State University. 2020.Vol. 33. No. 1. 93-p.

8. 1 Zorkin V.D. Law in the digital world. Reflection on the sidelines of the St. Petersburg International Legal Forum // Rossiyskaya Gazeta. 2018.29 May.

9. ${ }^{1}$ Sitdikov A. Digital law - the legal basis of the digital economy. // Odillik mezoni. 2020. No. 11, P.50.

10. ${ }^{1}$ Rodionov L.A. On the question of the legal characteristics of digital technologies in civil law // International Journal of the Humanities and Natural Sciences. 2019. No. 4-3. S. 188-190. DOI: 10.24411 / 2500-1000-2019-10835.

11. ${ }^{1}$ Rozhkova M.A. Digital money: mobile fiat currency, currency of virtual worlds, currency of corporate value, cryptocurrency and national cryptocurrency [Electronic resource]. Zakon.ru. 2019.7 October.

URL: https://zakon.ru/blog/2019/10/7/cifrovye_dengi_mobilnaya_fiatnaya_valyuta_valyuta_virtualnyh_ mirov_valyuta_korporativnogo_znacheniya? Fbclid = IwAR1nk3VGnk6lFJUN4alv0.

12. ${ }^{1}$ On attracting investments using investment platforms and on amendments to certain legislative acts of the Russian Federation: Feder. the law Ros. Federation from 2 aug. 2019 No. 259-FZ // Collected. legislation Ros. Federation. 2019. No. 31, Art. 4418.

13. ${ }^{1}$ Sannikova L.V., Kharitonova Yu.S. Legal essence of new digital assets // Law. 2018. No. 9. P. 86-95. ${ }^{1}$ Digital rights as a new object of civil law / L. Novoselova, A. Gabov, A. Saveliev, A. Genkin, S. Sarbash, A. Asoskov, A. Semenov, R. Yankovsky, A. Zhuravlev, A. Tolkachev, A. Kamelkova, M. Uspensky, R. Krupenin, V. Kisly, M. Zhuzhzhalov, V. Popov, M. Agranovskaya // Zakon. 2019. No. 5. P. 31-54.

14. ${ }^{1}$ Istomin M.A. On the question of the essence of digital rights. // Ural journal of legal research, 2019. №5. 626-p.

15. Fayziyev Shokhrud Farmonovich Medical law and features of legal relations arising in the provision of medical services. International journal of pharmaceutical research Volume 11, Issue 3, July - Sept, 2019 P. $1197-1200 \quad$ doi:10.31838/ijpr/2019.11.03.088 http://www.ijpronline.com/ViewArticleDetail.aspx?ID=11016

16. Bryanskaya Elena, Fayziev Shokhrud, Altunina Anna, Matiukha Alena Topical Issues of an Expert Report in the Process of Proving in a Criminal Examination. International Journal of Engineering and Advanced Technology (IJEAT) ISSN: 2249 - 8958, Volume-9 Issue-1, October 2019 5345-5349 DOI: 10.35940/ijeat.A2946.109119 content/uploads/papers/v9i1/A2946109119.pdf

17. Fayziev Shokhrud (2019) Legal Aspects of Transplantology in the Republic of Uzbekistan. Systematic Reviews in Pharmacy, ISSN: 0976-2779, Vol: 10, Issue: 2, Page: 44-47 doi:10.5530/srp.2019.2.08 1575419211.pdf?1586863081 http://www.sysrevpharm.org//fulltext/196-

18. Tulaganova, G. Some issues of observance of international legal norms of fight against legalization of criminal incomes in the Republic of Uzbekistan Journal of Advanced Research in Dynamical and Control Systems 12(2 Special Issue), c. 143-155

19. Bazarova D. Some problems of counteracting crimes related to laundering of illegal proceeds in Uzbekistan Journal of Advanced Research in Dynamical and Control Systems. Volume 11, Issue 7, 2019, Pages 873-885 